\title{
Influence of visceral and subcutaneous fat in bone mineral density of obese adolescents
}

\author{
A influência da gordura visceral e subcutânea na \\ densidade mineral óssea de adolescentes obesos
}

Raquel M. S. Campos', Marise Lazaretti-Castro², Marco Túlio de Mello3, Lian Tock', Patricia L. Silva', Flávia C. Corgosinho', June Carnier', Aline de Piano', Priscila L. Sanches', Deborah C. L. Masquio ${ }^{4}$, Sergio Tufik ${ }^{3}$, Ana R. Dâmaso 1,4,5

${ }^{1}$ Graduate Studies Program in Nutrition, Universidade Federal de São Paulo (Unifesp)، São Paulo, SP, Brazil 2 Endocrinology Department Unifesp, São Paulo, SP, Brazil ${ }^{3}$ Psychobiology Department, Unifesp, São Paulo, SP, Brazil ${ }^{4}$ Graduate Studies Program in Interdisciplinary Health Sciences, Unifesp, São Paulo, SP, Brazil ${ }^{5}$ Biosciences Department, Unifesp, São Paulo, SP, Brazil

Correspondence to: Raquel M. S. Campos Programa de Pós-Graduação em Nutrição, Escola Paulista de Medicina, Universidade Federal de São Paulo

Rua Francisco de Castro, 93 04020-050 - São Paulo, SP, Brazi raquelmunhoz@hotmail.com

Received on 24/Mar/2011 Accepted on 20/Dec/2011

\begin{abstract}
Objective: To verify the influence of visceral and subcutaneous fat, as well adipokines in bone mineral density (BMD) in obese adolescents. Subjects and methods: The study involved 125 postpubertal obese adolescents (45 boys and $80 \mathrm{girls}$ ). Anthropometric measurements, body composition, visceral and subcutaneous fat, and BMD were determined. Leptin, adiponectin, and insulin levels also analyzed. Results: Data demonstrated a negative relationship between BMD with insulin resistance, visceral fat and leptin concentration; and bone mineral content with visceral/subcutaneous ratio. Positive association between BMD and subcutaneous fat was observed. Conclusions: Visceral fat and insulin resistance, as well as visceral/subcutaneous ratio and leptin concentration, were negative predictors of BMD in boys and girls, respectively. However, subcutaneous fat had a protective influence in BMD only in boys. Arq Bras Endocrinol Metab. 2012;56(1):12-8
\end{abstract}

Keywords

Adolescent; visceral fat; subcutaneous fat; bone mass

\section{RESUMO}

Objetivo: Verificar a influência da gordura visceral e subcutânea, assim como das adipocinas na densidade mineral óssea (DMO) em adolescentes obesos. Sujeitos e métodos: 0 estudo envolveu 125 adolescentes obesos pós-púberes. Medidas antropométricas, composição corporal, gordura visceral e subcutânea e DMO foram determinadas. Níveis de leptina, adiponectina e insulina foram analisados. Resultados: Os dados demonstraram associação negativa entre DMO com resistência insulínica, gordura visceral e concentração de leptina; e conteúdo mineral ósseo com a razão visceral/subcutânea. Associação positiva entre DMO e gordura subcutânea foi observada. Conclusões: Gordura visceral, resistência insulínica, razão visceral/subcutânea e concentração de leptina foram preditores negativos da DMO em meninos e meninas, respectivamente. Entretanto, a gordura subcutânea demonstrou exercer influência positivamente na DMO somente nos meninos. Arq Bras Endocrinol Metab. 2012;56(1):12-8

Descritores

Adolescente; gordura visceral; gordura subcutânea; massa óssea

\section{INTRODUCTION}

$\mathrm{O}$ besity is a worldwide epidemic with high prevalence among citizens of European countries (1) and the USA, including the pediatric population. By 2030, the percentage of obese children will double (2). In Brazil, recent research utilizing the WHO standard for obesity determined that one in every three children aged 5 to 9 years is overweight. In addition, $20 \%$ of Brazilian adolescents are overweight (3).

Due the important skeletal properties of adipocyte hormonal products, the impact of obesity in bone metabolism is becoming a focus of attention. In this re- 
gard, controversial issues related to obesity and bone mass have been raised, some data suggest that the type of body fat distribution, especially visceral adipocytes, are linked to the secretion of proinflammatory cytokines that can act negatively on bone metabolism (4-7).

Moreover, it was recently demonstrated that hyperleptinemia was linked to the same inflammatory process present in obesity, while adiponectin presented opposite effects, exerting an anti-inflammatory role (8). The leptin/adiponectin ratio represents a proinflammatory biomarker in obesity, and its relationship with bone metabolism in adolescents has not been well explored. An imbalance between these adipokines may suggest an intrinsic influence in the development of metabolic diseases, including changes in bone metabolism (9).

Furthermore, in relation to bone mass, changes in proinflammatory cytokines cause a breakdown in bone metabolism and may induce a predominance of bone resorption, which could possible result in osteopenia and increased risk of fractures in obese women, compared with their leaner counterparts $(10,11)$. However, these contributions varied according to race (10). Indeed, data are conflicting regarding the association of visceral and subcutaneous fat in bone metabolism, with studies reporting positive, negative, or lack of association $(12,13)$.

Thus, the present study aimed at verifying the interaction of visceral and subcutaneous fat with bone mass, and the influence of pro-anti/inflammatory adipokines and gender in bone mass of obese adolescents.

\section{MATERIAL AND METHODS}

\section{Population}

This study involved 125 postpubertal obese adolescents ( 45 boys and 80 girls) between 14 and 18 years old. Inclusion criteria were Tanner stage 5 (14), primary obesity, BMI greater than $30 \mathrm{~kg} / \mathrm{m}^{2}$ (BMI $>95^{\text {th }}$ percentile). Exclusion criteria were the use of birth control pills, cortisone, anti-epileptic drugs, history of renal disease, alcohol intake, smoking, obesity due to secondary endocrine disorders, history of fractures and long-term supplementation of calcium, and/or other drugs that may affect bone metabolism. The study was conducted based on the principles of the Declaration of Helsinki, and was approved by the ethics committee on research at the Universidade Federal de São Paulo - Unifesp (\#0135/04) Clinical Trial.gov: NCT01358773. All procedures were clearly explained to those responsible for the volunteers, and written consent was obtained from the parent/legal guardian of each volunteer.

\section{Anthropometric measurements}

Each volunteer was weighted on a regular scale (Filizola - Brazil) wearing light clothes and no shoes. Weight was recorded to nearest $0.1 \mathrm{~kg}$, and height was measured using a wall-mounted stadiometer (Sanny - model ES 2030) to the nearest $0.5 \mathrm{~cm}$. After obtaining weight and height, body mass index (BMI) was calculated as the weight divided by height squared $\left(\mathrm{kg} / \mathrm{m}^{2}\right)$. Mean BMI $( \pm \mathrm{SD})$ was $36.5 \pm 4.6 \mathrm{~kg} / \mathrm{m}^{2}$.

\section{Serum analysis}

Blood samples were collected in the outpatient clinic at $8 \mathrm{am}$, after overnight fast. Leptin and adiponectin concentrations were measured by commercial immunoassays kits (eBioscience, San Diego, CA; and R \& D Systems, Minneapolis, MN, respectively) according to the manufacturer's instructions. Insulin resistance was assessed by the homeostatic model assessment (HOMA-IR). HOMA-IR was calculated using fasting blood glucose (FBG) and immunoreactive insulin (I): [FBG $(\mathrm{mg} / \mathrm{dL}) \times \mathrm{I}(\mathrm{mU} / \mathrm{L})] / 405$. HOMA-IR data were analyzed according to reference values described by Schwimmer and cols. (15). The coefficients of variation for the biochemical parameters analyzed were: insulin $(\mu \mathrm{U} / \mathrm{mL}) 3.3 \%$, adiponectin $(\mu \mathrm{g} / \mathrm{L}) 4.5 \%$, and leptin $(\mathrm{ng} / \mathrm{mL}) 4.07 \%$.

\section{Measurement of visceral and subcutaneous fat}

Abdominal ultrasound and measurements of visceral and subcutaneous adipose tissue were performed by the same physician, who was blind to the conditions of the volunteers. The examination was performed by a specialist in imaging diagnosis using a multifrequency transducer (broadband) at $3.5 \mathrm{MHz}$, which reduces the risk of error. The intra assay coefficient of variation for ultrassound (US) was $0.8 \%$. This method was previously standardized for obese adolescents. Ultrasound measurement of subcutaneous fat tissue was defined as the distance between the skin and ex- 
ternal face of the rectus abdominis. Visceral fat tissue was defined as the distance between the inner face of the rectus abdominis and the anterior wall of the aorta. The parameters were based on previous methodological descriptions (16).

\section{Bone mineral density and bone mineral composition}

Determination of bone mineral content (BMC) in grams ( $\mathrm{g}$ ), and bone mineral density (BMD) in $\mathrm{g} /$ $\mathrm{cm}^{2}$, was performed per unit of bone densitometry by attenuation of dual-energy X-ray absorptiometry (DXA), using Hologic QDR 4200 (Hologic, Bedford, MA) with the appropriate software for bone assessment. Total body scan requires the volunteer to keep the right distance between his or her arms and legs according to the manufacturer's specifications (17). To obtain statistically precise measurements, $68 \%$ of the exams were repeated within IDP $( \pm 0.8 \%$ fat, $210 \mathrm{~g} \pm$ tissue mass, $\pm 520 \mathrm{~g}$ fat mass, \pm $610 \mathrm{~g}$ whole body lean mass to total).

\section{Statistical analysis}

All data were analyzed using Statistica version 7.0 for Windows Vista. Statistical significance was set at $\alpha \leq 5 \%$. Normality of the data was verified with the Kolmogorov-Smirnov test. In the boys group, nonparametric variables were insulin, HOMA-IR, pelvis $\mathrm{BMD}$, lean tissue, leptin and Lep/Adip ratio (ratio between leptin and adiponectin concentrations). In the girls group, nonparametric variables were spine BMD and Lep/Adip ratio.

The other variables showed normal distribution in the two groups. Parametric data were expressed as mean $\pm \mathrm{SD}$, and nonparametric data were expressed as medians, minimum and maximum values.

Statistical analyses were performed with the sample divided by gender, and were carried out to compare the variables analyzed by Student's t test for independent groups. Correlations were established by means of the Pearson test, for parametric data, and Spearman test, for nonparametric data. Finally, dependencies between the variables were verified using multiple and simple linear regression analysis.

\section{RESULTS}

The study sample consisted of postpubertal obese adolescents divided in two groups according to gender, matched for age, weight $(\mathrm{kg})$, and body mass index $\left(\mathrm{kg} / \mathrm{m}^{2}\right)$. There were no significant differences between groups for subcutaneous fat $(\mathrm{cm})$, insulin $(\mu \mathrm{U} / \mathrm{mL})$, HOMA-IR, age (years), BMI $\left(\mathrm{kg} / \mathrm{m}^{2}\right)$, total BMD $(\mathrm{g} /$ $\left.\mathrm{cm}^{2}\right)$, lower limb BMD $\left(\mathrm{g} / \mathrm{cm}^{2}\right)$, pelvis BMD $\left(\mathrm{g} / \mathrm{cm}^{2}\right)$, spine BMD $\left(\mathrm{g} / \mathrm{cm}^{2}\right), \mathrm{BMD}(\mathrm{Z}$-score $)$, and total fat $(\%)$. Boys presented higher results for visceral fat $(\mathrm{cm})$, glucose $(\mu \mathrm{U} / \mathrm{mL})$, weight $(\mathrm{kg})$, height $(\mathrm{m}), \mathrm{BMC}(\mathrm{g})$, total fat $(\%)$, and total lean tissue $(\mathrm{kg})$ compared to girls. Descriptive data are presented in the table 1.

Specifically for the boys group, correlation analysis demonstrated a positive association between total $\operatorname{BMD}\left(\mathrm{g} / \mathrm{cm}^{2}\right)$ and weight $(\mathrm{kg})(\mathrm{r}=0.38, \mathrm{p}=0.01)$; lower $\operatorname{limb}$ BMD and subcutaneous fat $(\mathrm{r}=0.37, \mathrm{p}=$ $0.00)$; glucose $(\mathrm{r}=0.29, \mathrm{p}=0.02)$ and total fat $(\mathrm{kg})(\mathrm{r}$ $=0.34, \mathrm{p}=0.02)$; and BMD $(\mathrm{z}$-score $)$ and visceral fat $(\mathrm{r}=0.31, \mathrm{p}=0.03)$, insulin $(\mathrm{r}=0.36, \mathrm{p}=0.01)$, and HOMA-IR $(\mathrm{r}=0.36, \mathrm{p}=0.01)$. A negative associa-

Table 1. Descriptive anthropometric data, body composition and biochemical parameters in 125 obese adolescents

\begin{tabular}{|c|c|c|c|}
\hline Variables & $\begin{array}{c}\text { Boys } \\
(n=45)\end{array}$ & $\begin{array}{c}\text { Girls } \\
(n=80)\end{array}$ & $\underset{\text { value }^{\star}}{\mathbf{p}}$ \\
\hline Age (years) & $16.04 \pm 1.87$ & $16.56 \pm 1.56$ & 0.100 \\
\hline Weight (kg) & $105.85 \pm 14.73$ & $97.30 \pm 14.63$ & 0.002 \\
\hline Height (m) & $1.71 \pm 0.07$ & $1.63 \pm 0.07$ & 0.000 \\
\hline Total fat (kg) & $43.1 \pm 10.8$ & $46.4 \pm 99.2$ & 0.084 \\
\hline Total fat (\%) & $40.31 \pm 6.41$ & $48.05 \pm 5.61$ & 0.000 \\
\hline Lean tissue (kg) & $56.4(24-71)^{\dagger}$ & $40.7 \pm 14.2$ & 0.015 \\
\hline Visceral fat (cm) & $4.93 \pm 1.58$ & $4.18 \pm 1.40$ & 0.007 \\
\hline Subcutaneous fat (cm) & $3.38 \pm 0.82$ & $3.69 \pm 0.92$ & 0.061 \\
\hline Visc/Subc ratio & $1.49 \pm 0.44$ & $1.19 \pm 0.50$ & 0.001 \\
\hline BMI $\left(\mathrm{kg} / \mathrm{m}^{2}\right)$ & $36.26 \pm 4.40$ & $36.57 \pm 4.76$ & 0.716 \\
\hline Glucose $(\mu \mathrm{U} / \mathrm{mL})$ & $5.21 \pm 0.47$ & $5.00 \pm 0.36$ & 0.007 \\
\hline Insulin $(\mu \mathrm{U} / \mathrm{mL})$ & $19(4.90-60.3)^{\dagger}$ & $17.26 \pm 6.97$ & 0.296 \\
\hline HOMA-IR & $3.89(0.97-16.1)^{\dagger}$ & $3.85 \pm 1.62$ & 0.129 \\
\hline Adiponectin ( $\mu \mathrm{g} / \mathrm{L})$ & $7.39 \pm 3.11$ & $7.86 \pm 3.41$ & 0.67 \\
\hline Leptin (ng/mL) & $23.57(1.23-97.44)^{\dagger}$ & $36.3(1.15-100)^{\dagger}$ & 0.03 \\
\hline Lep/Adip ratio & $3.35(0.15-21.9)^{\dagger}$ & $3.91(0.17-38.9)^{\dagger}$ & 0.09 \\
\hline Total BMD (g/cm²) & $1.24 \pm 0.14$ & $1.23 \pm 0.09$ & 0.743 \\
\hline Lower limb BMD (g/cm²) & $1.32 \pm 0.25$ & $1.30 \pm 0.10$ & 0.632 \\
\hline Pelvis BMD (g/cm²) & $(0.92-1.01)^{\dagger}$ & $1.28 \pm 0.11$ & 0.177 \\
\hline Spine BMD (g/cm²) & $1.06 \pm 0.17$ & $1.23(0.78-9.14)^{\dagger}$ & 0.209 \\
\hline Total BMD (Z-score) & $1.2 \pm 1.17$ & $1.4 \pm 1.08$ & 0.296 \\
\hline Total BMC (g) & $2981 \pm 518$ & $2641 \pm 574$ & 0.001 \\
\hline
\end{tabular}

* Statistical significance set at $p<0.05 ;{ }^{\dagger}$ nonparametric data described as median and minimum and maximum values. BMI: body mass index; BMC: bone mineral content; BMD: bone mineral density; HOMA-IR: insulin resistance index; Visc/Subc ratio: ratio between visceral and subcutaneous fat; Adip/Lep ratio: ratio between adiponectin and leptin concentration. 
tion was observed between pelvis BMD and total fat (\%) $(\mathrm{r}=-0.40, \mathrm{p}=0.01)$. In the girls group, negative associations were found between spine BMD and leptin $(\mathrm{r}=-0.30, \mathrm{p}=0.03) ; \mathrm{visc} / \mathrm{subc}$ ratio (ratio between visceral and subcutaneous fat $)$ and $\mathrm{BMC}(\mathrm{r}=-0.22$, $\mathrm{p}=0.04)$; and BMD ( $\mathrm{z}$-score) and visc/subc ratio $(\mathrm{r}$ $=-0.29, \mathrm{p}=0.00)$. Furthermore, a positive association was found between total BMD and height $(r=0.37$, $\mathrm{p}=0.03)$; and between BMD ( $\mathrm{z}$-score), subcutaneous fat $(\mathrm{r}=0.29, \mathrm{p}=0.00)$ and weight $(\mathrm{r}=0.39, \mathrm{p}=0.00)$ (Table 2).

Table 2. Data from correlation analysis

\begin{tabular}{lccc}
\hline & Variables & $\begin{array}{c}\text { r } \\
\text { value }\end{array}$ & $\begin{array}{c}\mathbf{p} \\
\text { value }\end{array}$ \\
\hline Boys $(\mathbf{n}=\mathbf{4 5})$ & & & \\
\hline Total BMD $\left(\mathrm{g} / \mathrm{cm}^{2}\right)$ & Weight $(\mathrm{kg})$ & 0.38 & 0.01 \\
Lower limb BMD $\left(\mathrm{g} / \mathrm{cm}^{2}\right)$ & Subcutaneous fat $(\mathrm{cm})$ & 0.37 & 0.00 \\
& Glucose $(\mu \mathrm{U} / \mathrm{mL})$ & 0.29 & 0.02 \\
& Total fat $(\mathrm{kg})$ & 0.34 & 0.02 \\
Pelvis BMD $\left(\mathrm{g} / \mathrm{cm}^{2}\right)$ & Total fat $(\mathrm{kg})$ & -0.40 & 0.01 \\
BMD $(\mathrm{Z}-\mathrm{score})$ & Visceral fat $(\mathrm{cm})$ & 0.31 & 0.03 \\
& Insulin $(\mu \mathrm{U} / \mathrm{ml})$ & 0.36 & 0.01 \\
& HOMA-IR & 0.36 & 0.01 \\
\hline Girls $(\mathbf{n}=\mathbf{8 0})$ & & & \\
\hline Spine BMD $\left(\mathrm{g} / \mathrm{cm}^{2}\right)$ & Leptin $(\mathrm{ng} / \mathrm{mL})$ & -0.30 & 0.02 \\
Total BMC $(\mathrm{g})$ & Visc/subc ratio & -0.22 & 0.04 \\
Total BMD $\left(\mathrm{g} / \mathrm{cm}^{2}\right)$ & Height $(\mathrm{m})$ & 0.37 & 0.03 \\
BMD $(\mathrm{Z}-\mathrm{score})$ & Subcutaneous fat $(\mathrm{cm})$ & 0.29 & 0.00 \\
& Weight $(\mathrm{kg})$ & 0.39 & 0.00 \\
& Visc/subc ratio & -0.29 & 0.00 \\
\hline
\end{tabular}

Statistical significance set at $p<0.05$; BMC: bone mineral content; BMD: bone mineral density.

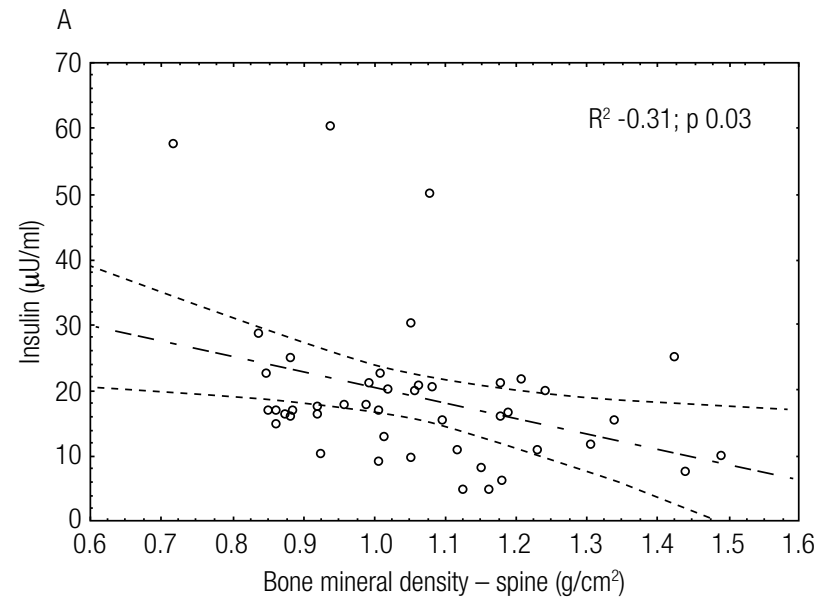

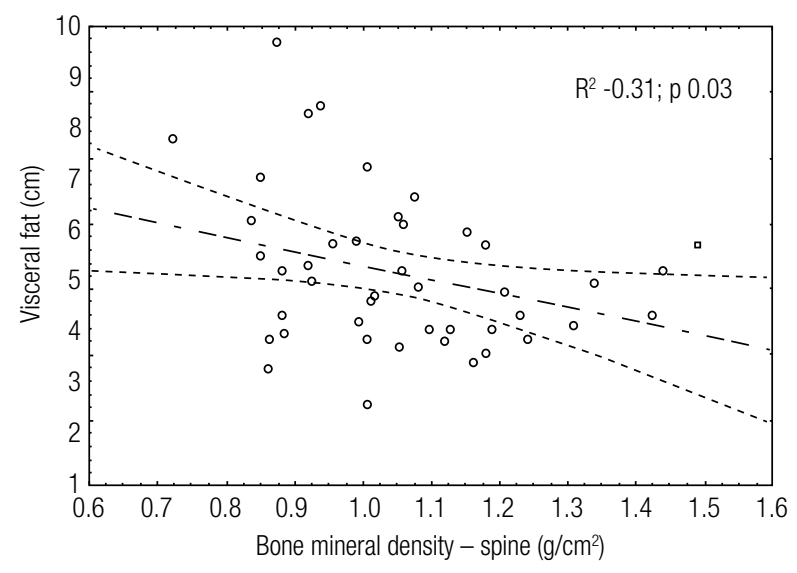

Figure 2. Simple linear regression adjusted for visceral fat $(\mathrm{cm})$ for data on bone mineral density in the spine of boys: $r^{2}=-0.31, p=0.03$.

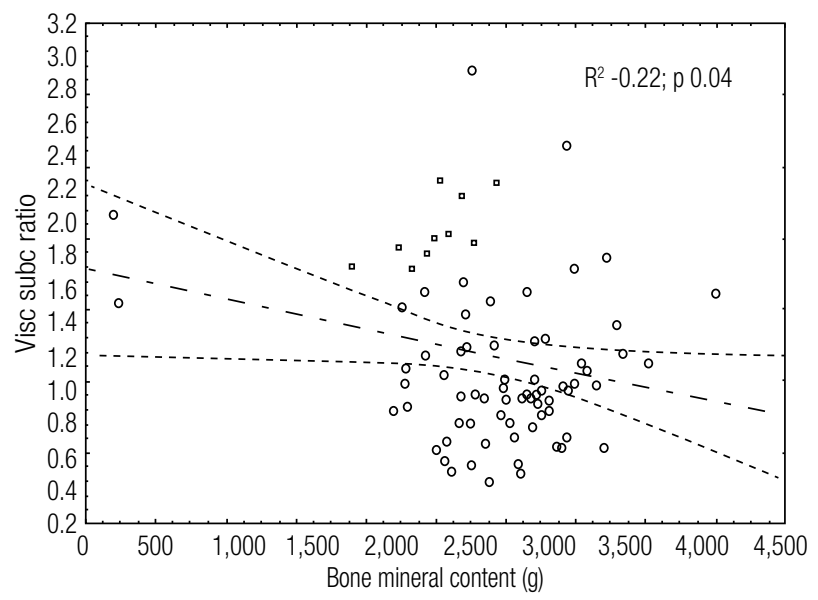

Figure 3. Simple linear regression adjusted for visc/subc ratio for data on bone mineral content in girls: $r^{2}=-0.22, p=0.04$.

Figure 1. Simple linear regression adjusted for (a)insulin $(\mu \mathrm{U} / \mathrm{mL}) \mathrm{r}^{2}=-0.35, p=0.01$, and $(b) H O M A-I R r^{2}=-0.34, p=0.01$ for data on bone mineral density in the spine of boys. 
Simple linear regression showed that some variables can be considered predictors of reduced spine BMD in boys. These variables were insulin $(\mu \mathrm{U} / \mathrm{mL}) \mathrm{r}^{2}=-0.35$, $\mathrm{p}=0.01 ;$ HOMA-IR $\mathrm{r}^{2}=-0.34, \mathrm{p}=0.01$ (Figure $\mathrm{l}$ $\mathrm{A}-\mathrm{B}$ ); and visceral fat $\mathrm{r}^{2}=-0.31, \mathrm{p}=0.03$ (Figure 2). In the girls group, the visc/subc ratio was a negative predictor of $\mathrm{BMC}^{2}=-0.22, \mathrm{p}=0.04$ (Figure 3 ).

\section{DISCUSSION}

It is well-established in the literature that fat deposition in regional, visceral or subcutaneous compartments is related to the development of some diseases $(18,19)$. In a recent trial with adolescent students, high prevalence of central obesity and hypertension was observed. Central obesity was more frequent in those aged 18 to 20 years, in smokers, and in those that drank alcohol (20).

One of the most important findings of the present study was that bone mineral density of lower limbs correlated positively with subcutaneous fat; and that visceral fat was a negative predictor of spine and total bone mineral density $\left(\mathrm{g} / \mathrm{cm}^{2}\right.$ and $\mathrm{Z}$-score $)$, only in boys. In the girls group, bone mineral density ( $\mathrm{z}$-score) was positively associated with subcutaneous fat, and negatively correlated with the visc/subc ratio.

Others studies in adults have found that visceral and subcutaneous fat have opposite effects on bone structure. They support the hypothesis that visceral fat plays a pathogenic role, whereas subcutaneous fat is beneficial to peak bone mass $(12,21,22)$.

Moreover, several factors may be important contributors to bone mineral density during childhood and adolescence. These factors include gender, genetic inheritance and changes in body dimensions throughout the child's life, height, physical activity, calcium intake, hormonal status, and subcutaneous and visceral fat accumulation $(23,24)$.

It is known that obesity causes a complete change in hormonal and adipokine profile, resulting in altered bone mass (9). In agreement with previous findings, the present investigation showed that visceral fat deposition and visceral/subcutaneous ratio were negative predictive factors for bone mineral density in the patients analyzed.

In fact, previous studies of our group showed that visceral fat greater than $5.53 \mathrm{~cm}$ for boys and $4.5 \mathrm{~cm}$ for for girls was a predictive risk factor for Nonalcoholic Fatty Liver Disease (NAFLD), an emerging risk factor in metabolic syndrome $(24,25)$. However, we did not investigate the association between NAFLD and bone health in the present study. Together, these results suggest an intrinsic role between visceral fat and the development of bone metabolic diseases in the young obese patients (Table 1, Figures 2 and 3 ). This hypothesis needs to be confirmed by future investigations.

Moreover, secretions from visceral adipose tissue are directly related with the development of insulin resistance and type 2 diabetes (18). In contrast, subcutaneous fat seems to have a protective influence, preventing the onset of atherosclerosis, which corroborate our findings on the role of fat deposition on bone mineral density in both boys and girls (Table 2).

Another relevant finding observed in the present study was that increased insulin concentration and HOMA-IR were considered negative predictors of spine bone mineral density in boys. It is known that insulin induces osteoblast proliferation and collagen production; however, its action is not fully elucidated in patients with signs of insulin resistance (9,26-29).

It is important to note that in our research, both boys and girls were insulin-resistant in the same period of adolescence, as demonstrated in table 1 , reinforcing the influence of insulin homeostasis in the etiology of bone diseases. The role of the insulin resistance still is quite controversial in the literature (30-32). One important issue that needs to be explored is that the association observed in the present investigation was only confirmed in boys. As a partial explanation for this discrepancy between genders, we hypothesized that obese boys showed more pronounced visceral fat compared with girls. However, this hypothesis needs to be confirmed with a larger sample size.

Furthermore, studies have found that obese adolescents presented the framework for metabolic syndrome associated with the presence of insulin resistance and visceral fat $(24,33)$. In addition, hyperinsulinemia is associated with impaired function of the IGF-1 axis, which is involved in determining bone thickness and length, density and architecture of the mature skeleton (34). IGF-1 axis impairment would result in low bone mineral density observed in children, adolescents and adults $(28,35)$.

Interestingly, correlation analysis with that leptin concentration was a negative predictor of bone mineral density in obese girls. It is important to note that hyperleptinemic state was found in the analyzed group, suggesting that leptin deficiency and/or resistance, as well as other proinflammatory adipokines involved in 
bone resorption may promote osteoporosis (22). Corroborating our findings, another study reported that both abdominal adipose tissue and leptin were negatively associated with BMC in Latino overweight children of both genders (36).

However, these findings need to be confirmed in future studies, since a review of the literature did not show an association between leptin and bone mass in children and adolescents. However, in postmenopausal women, leptin showed to be a present a predictor of bone mass, and this association was not confirmed in a state of hyperleptinemia. Altogether, the action of leptin on the bones appears to be complex, and both positive and negative effects have been reported. It appears that leptin action may depend on their location of action, differentiating the effects central of peripheral. (37-39).

In addition, recent review showed that excessive leptin secretion and/or decreased production of adiponectin in obesity may either directly affect bone formation or indirectly affect bone resorption through an up-regulated proinflammatory cytokine production. In fact, adiponectin was associated with a protective effect against osteoporosis development $(26,39)$. However, the concentration of this anti-inflammatory adipokine was reduced in obese adolescents and adults (40), which may partially explain why we were not able to show a protective role of adiponectin in bone mineral density in the obese adolescents in a state of hyperleptinemia (Table 1). Moreover, both osteoblasts (boneforming cells) and adipocytes (energy-storing cells) are derived from a common mesenchymal stem cell, and agents that inhibit adipogenesis stimulate osteoblast differentiation and vice-versa, those inhibiting osteoblastogenesis increase adipogenesis. This mechanisms may contribute to the influence of obesity in bone metabolism (39).

Finally, the lack of a control group, of normal weight, represents a limitation of the present study. Further investigations that include a control group are needed. This study demonstrated that visceral fat and insulin resistance, as well as visceral/subcutaneous ratio and leptin concentration, were negative independent predictors of bone mineral density in boys and girls, respectively. However, subcutaneous fat had a protective influence in bone mineral density only in boys. Further exploration of the protective role of adiponectin in bone mineral density is needed to improve clinical practice.
Acknowledgments: AFIP, Fapesp, CNPq and Capes supported the CEPE - Multidisciplinary Obesity Intervention Program. Fapesp (CEPID/ Sleep \#9814303-3 S.T), Fapesp (2006/00684-3; 2008/53069-0; 2011/50356-0), Unifesp/ EPM. We would specially like to thank our patients and their parents.

Disclosure: no potential conflict of interest relevant to this article was reported.

\section{REFERENCES}

1. World Health Organization. Obesity: preventing and managing the global epidemic. WHO Obesity Technical Report Series 894; Geneva 2000; World Health Organization.

2. Wang Y, Beydoun MA, Liang L, Caballero B, Kumanyika SK. Will all Americans become overweight or obese? Estimating the progression and cost of the US obesity epidemic. Obesity (Silver Spring). 2008;16(10):2323-30.

3. Pesquisa de Orçamentos Familiares. Comunicação Social POF 2008-2009. In: Estatística IBGE, editor.

4. CaoYL, Wang YX, Wang DF, Meng X, Zhang J. Correlation between omentalTNF-alpha protein and plasma PAI-1 in obesity subjects. Int J Cardiol. 2008;128:99-405.

5. Trayhurn P, Wood IS. Signaling role of adipose tissue: adipokines and inflammation in obesity. Biochem SocTrans. 2005;33(5):1078-81.

6. Cao YL, Hu CZ, Meng X, Wang DF, Zhang J. Expression of TNF alpha protein in omental and subcutaneous adipose tissue in obesity. Diabetes Res Clin Pract. 2008;79:214-9.

7. Bandeira F, Lazaretti-Castro M, Bilezikian JP. Hormones and bone. Arq Bras Endocrinol Metab. 2010;54(2):85-6.

8. Hall J, Roberts R, Vora N. Energy homoeostasis: the roles of adipose tissue-derived hormones, peptide $Y Y$ and Ghrelin. Obes Facts. 2009;2(2):117-25.

9. do Prado WL, de Piano A, Lazaretti-Castro M, de Mello MT, Stella SG, Tufik S, et al. Relationship between bone mineral density, leptin and insulin concentration in Brazilian obese adolescents. J Bone Miner Metab. 2009;27(5):613-19.

10. Afghani A, Goran MI. Racial differences in the effects of subcutaneous and visceral fat on bone mineral content in pre-pubertal children. CalcifTissue Int. 2006;79(6):383-8.

11. Garnero P, Sornay-Rendu E, Claustrat B, Delmas PD. Biochemical markers of bone turnover, endogenous hormones and the risk of fractures in postmenopausal women: the OFELY study. J Bone Miner Res. 2000;15(8):1526-36.

12. Gilsanz V, Chalfant J, Mo AO, Lee DC, Dorey FJ, Mittelman SD. Reciprocal relations of subcutaneous and visceral fat to bone structure and strength. J Clin Endocrinol Metab. 2009;94(9):3387-93.

13. Lac G, Cavalie H, Ebal E, Michaux O. Effects of a high fat diet on bone of growing rats. Correlations between visceral fat, adiponectina and bone mass density. Lipids Health Dis. 2008;7:16.

14. Tanner JM, Whitehouse $\mathrm{RH}$. Clinical longitudinal standards for height, weight, height velocity, weight velocity, and stages of puberty. Arch Dis Child. 1976;51(3):170-9.

15. Schwimmer JB, Deutsch R, Rauch JB, Behling C, Newbury R, Lavine JE. Obesity, insulin resistance, and other clinicopathological correlate of pediatric nonalcoholic fatty liver disease. Pediatrics. 2003;143(4):500-5.

16. Ribeiro-Filho FF, Faria AN, Azjen S, Zanella MT, Ferreira SR. Methods of estimation of visceral fat: advantages of ultrasonography. Obes Res. 2003;11(12):1488-94.

17. Black E, Petersen L, Kreutzer M, Toubro S, Sorensen TI, Pedersen $O$, et al. Fat mass measured by DXA varies with scan velocity. Obes Res. 2002;10(2):69-77. 
18. Zoico E, Zamboni M, Di Francesco V, Mazzali G, Fantin F, De Pergola $G$, et al. Relation between adiponectin and bone mineral density in elderly post-menopausal women: role of body composition, leptin, insulin resistance, and dehydroepiandrosterone sulfate. J Endocrinol Invest. 2008;31(4):297-302.

19. Lee JM, Appugliese D, Kaciroti N, Corwyn RF, Bradley RH, Lumeng JC. Weight status in young girls and the onset of puberty. Pediatrics. 2007;119(3):624-30.

20. Griz LHM, Viégas $M$, Barros $M$, Griz AL, Freese $E$, Bandeira $F$. Prevalence of central obesity in a large sample of adolescentes from public school in Recife, Brazil. Arq Bras Endocrinol Metab. 2010;54(7):607-11.

21. Holbrook TL, Barret-Connor E. The association of lifetime weight and height control patterns with bone mineral density in an adult community. Bone Miner. 1993;20(2):141-42.

22. Russell M, Mendes N, Miller KK, Rosen CJ, Lee H, Klibanski A, et al. Visceral fat is a negative predictor of bone density measures in obese adolescent girls. J Clin Endocrinol Metab. 2010;95(3):1247-55.

23. Lorentzon M, Lorentzon R, Backstrom T, Nordstom P. Estrogen receptor gene polymorphism, but not estradiol levels, is related to bone density in health adolescent boys: a cross-sectional and longitudinal study. J Clin Endocrinol Metab. 1999;84(12):4597-601.

24. Janz K. Physical activity and bone development during childhood and adolescence. Implications for the prevention of osteoporosis. Minerva Pediatr. 2002;54(2):93-104.

25. Dâmaso AR, do Prado WL, de Piano A, Tock L, Caranti DA, Lofrano $\mathrm{MC}$, et al. Relationship between nonalcoholic fatty liver disease prevalence and visceral fat in obese adolescents. Dig Liver Dis. 2008;40(2):132-39.

26. Afghani A, Cruz ML, Goran MI. Impaired glucose tolerance and bone mineral content in overweight latino children with a family history of type 2 diabetes. Diabetes Care. 2005;28(2):372-78.

27. Pollock NK, Bernard PJ, Wenger K, Sudipta M, Gower BA, Allison $J \mathrm{D}$, et al. Lower bone mass in prepubertal overweight children with prediabetes. J Bone Miner Res. 2010;25(12):2760-9.

28. Nishiyama KK, Macdonald HM, Buie HR, Hanley DA, Boyd SK. Postmenopausal women with osteopenia have higher cortical porosity and thinner cortices at the distal radius and tibia than women with normal aBMD: an in vivo HR-pQCT study. J Bone Miner Res. 2009;25(4):882-90.
29. Wren TA, Liu X, Pitukcheewanont $P$, Gilsanz V. Bone acquisition in healthy children and adolescents: comparisons of dualenergy $x$ -ray absorptiometry and computed tomography measures. J Clin Endocrinol Metab. 2005;90(4):1925-28.

30. Thomas T, Burguera B, Melton LJ, Atkinson EJ, Fallon WM, Riggs $\mathrm{BL}$, et al. Role of serum leptin, insulin, and estrogen levels as potential mediators of the relationship between fat mass and bone mineral density in men versus women. Bone. 2001;29(2):114-20.

31. Jurimae J, Jurimae T, Leppik A, Kums TJ. The influence of ghrelin, adiponectin and leptin on bone mineral density in healthy postmenopausal women. Bone Miner Metab. 2008;26(6): 618-23.

32. Kontogianni MD, Dafni UG, Routsias JG, Skopouli FN. Blood leptin and adiponectin as possible mediators of the relation between fat mass and BMD in perimenopausal women. Bone Miner Res. 2004;19(4):546-51.

33. Caranti DA, Lazzer S, Dâmaso AR, Agosti F, Zennaro R, de Mello $\mathrm{MT}$, et al. Prevalence and risk factors of metabolic syndrome in Brazilian and Italian obese adolescents: a comparison study. Int J Clin Pract. 2008;62(10):1526-32.

34. Rosen C. Growth hormone and insulin-like growth factor- I treatment for metabolic bone diseases. In: Bilezikian JP, Raisz LG, Rodan GA, editors. Principles of bone biology. 2nd ed. San Diego: Academic Press; 2002. p. 1441-53.

35. Agbaht K, Gurlek A, Karakaya J, Bayraktar M. Circulating adiponectin represents a biomarker of the association between adiposity and bone mineral density. Endocrine. 2009;35(3):371-9.

36. Afghani A, Goran M. The interrelationships between abdominal adiposity, leptin and bone mineral content in overweight Latino children. Horm Res. 2009;72(2):82-7.

37. Borba VZC, Kulak CAM, Lazaretti-Castro M. Controle neuroendócrino da massa óssea: mito ou verdade? Arq Bras Endocrinol Metab. 2003;47(4):453-7.

38. Samra RA, Baba NH, Torbay N, Dib L, El-Hajj G, et al. High plasma leptin is not associated with higher bone mineral density in insulin-resistant premenopausal obese women. J Clin Endocrinol Metab. 2005:90(5):2588-94.

39. Cao JY. Effects of obesity on bone metabolism. J Orthop Surg Res. 2011;6:30.

40. Ondrak KS, Hackney AC. Body composition differences in normal weight, obese-overweight and anorexic adolescents: role of adipocytokines. Med Sport Sci. 2010;55:32-42. 